\title{
Supply chain management drivers and competitive advantage in manufacturing industry
}

\author{
Thu-Trang Thi Doan ${ }^{a^{*}}$
}

${ }^{a}$ Faculty of Finance and Banking, Industrial University of Ho Chi Minh City (IUH), Vietnam

\begin{tabular}{l}
\hline C H R O N I C L E \\
\hline Article history: \\
Received January 29, 2020 \\
Received in revised format March \\
20,2020 \\
Accepted May 62020 \\
Available online \\
May 62020 \\
\hline Keywords: \\
Supply Chain Management \\
SCM drivers \\
Competitive Advantage \\
Manufacturing Industry \\
Vietnam
\end{tabular}

\section{A B S T R A C T}

Supply chain management (SCM) plays a major role in allowing manufacturing companies to achieve competitive advantage. However, only few studies have been investigated in manufacturing industry, particularly on the relationship between SCM drivers and competitive advantage. Therefore, the objective of this study is to explore the impact of supply chain management drivers on competitive advantage in Vietnamese manufacturing companies. By adopting the exploratory factor analysis (EFA), a multiple regression analysis, the author finds out that the SCM drivers including facilities, inventory, transportation, information, sourcing and pricing are strongly related to competitive advantage in the manufacturing. The results contribute to the current literature on supply chain and they are essential for supply chain in manufacturing industry by acknowledging the influence of SCM drivers on competitive advantage.

\section{Introduction}

In an integrated economy, Vietnamese manufacturing companies are not only in competition with each other but also with foreign companies. Competition in the global market is becoming so tough that manufacturing companies are facing more pressure which requires the reduction on cost, improvement in product quality and customer satisfaction. They are required to ensure prompt manufacture, comprehensive quality control in the aim of improving quality, enhancing performance and minimizing delivery time. In the context of a tough competition, companies start to recognize potential benefits and importance of supply chain management. Nowadays, more attention is devoted on supply chain management in order to improve company competitive advantage, control an effective cost as well as achieve customer satisfaction. Therefore, supply chain management (SCM) is really essential in enabling manufacturing companies gaining competitive advantage through maximizing customer values (Kamath 2016). More than that, Christopher (2016) interestingly stated the key role of SCM in the achievement of competitive advantage. It is necessary for manufacturers to gain competitive advantage through innovative ideas and solutions. As suggested by Mazlan and Ali (2006), if a problem of product delay occurs, the management has to oversee its causes and guarantee the proper implement of SCM to minimize the loss in value. Those in the middle management should take action with all levels of upstream and downstream suppliers as well as take responsibilities to ensure that the promised product or service will be delivered on time. SCM has emerged as a keystone to manufactures due to the fact that the current competitive world is driven by globalization (Rusli et al., 2013). SCM has become one of the most important means for manufactures to gain competitive advantage.

In the current globalized economy, supply chain management is a key factor in operation of companies generally and Vietnamese companies specifically. In particular, Vietnam is a manufacturing base of a number of high-valued industrial products namely textiles, cellphones, industrial steel, tea and coffee. The effective utilization of SCM will improve

* Corresponding author

E-mail address: doanthithutrang@iuh.edu.vn (T.-T. T. Doan)

(C) 2020 by the authors; licensee Growing Science.

doi: $10.5267 /$ j.uscm. 2020.5 .001 
performance in Vietnamese manufacturing industry. SCM then becomes a key factor which enables Vietnamese manufacturing companies to gain competitive advantage in the competition and boost the company growth. However, they are still facing many challenges in the utilization and improvement of SCM. In fact, very few theoretical and practical studies explore the correlation between supply chain management and competitive advantage in Vietnam. The analysis of this relationship is thus vital in enhancing competitive advantage of Vietnamese companies. This study investigates the impact of SCM drivers on competitive advantage of Vietnamese manufacturers. The paper adds to the existing literature and provides first evidence on the nexus between SCM drivers and competitive advantage in Vietnam.

\section{Literature review}

According to Lambert et al. (1998), supply chain is a network between its participants to distribute a product or service. Chopra and Meindl (2001) stated that supply chain consists of all stages which are directly or indirectly involved in satisfying customer needs. Janvier-James (2012) defines supply chain as a group of manufacturers, suppliers, distributors, retailers and transportation, information and other logistics management service providers that are engaged in providing goods to consumers. A supply chain includes both external and internal associates for the company. In short, supply chain comprises all groups and people participating, directly or indirectly, in fulfilling customer needs. The 1980s are marked as the origin of the term "supply chain management" which was initially believed to involve the management of purchase, warehouse and transportation in supply chain. This concept was later expanded as the management of all functions in supply chain (Chopra \& Meindl, 2001). According to Janvier-James (2012), supply chain management consists of the design and management of all activities involved in sourcing and purchasing, transformation, and all logistics management. It also includes the coordination and partnership with other partners which can be suppliers, mediators, third party service suppliers and customers. Basically, supply chain management combines supply and demand management within and across participants.

In this study, the author examines the influence of SCM drivers on company competitive advantage. The effective utilization of SCM drivers will improve company performance, thereby raising their competitive advantage. The SCM drivers include facilities, inventory, transportation, information, sourcing and pricing which mutually associate and support in improving how companies perform (Shahzadi et al., 2013). By their analysis, Matthew and Othman (2017) also confirmed on the relationship between the six SCM drivers and company competitive advantage. The findings, however, only revealed the significant influence of variables namely inventory, transportation, information and pricing on competitive advantage in Malaysia.

\section{Six drivers of SCM}

\section{- Facilities:}

Facilities are defined as where a product is stored, assembled and produced. More efficient management on facility role, ability and flexibility exerts a positive influence on performance of supply chain (Shahzadi et al., 2013). What primarily required here is to be more efficient and responsive. Manufacturers with warehouse facilities near to customers creates responsiveness to client needs but a poor performance due to a higher cost for warehousing. On the other hand, manufacturers who build less warehouses at main locations perform more effectively but respond more slowly to customer needs (Chopra \& Meindl, 2007). Facility decisions are regarded to be strategic because of its long-term impact on company finance. They also demonstrate the company basic initiative on its product development and distribution. According to Chotipanich (2004), facility decisions contribute to the success or failure of an organization. Matthew and Othman (2017) also considered the correlation between facility decisions and competitive advantage in manufacturing companies. The study, however, could not find the significant impact of facilities on competitive advantage of manufacturers. In Vietnam, facilities are expected to positively affect company competitive advantage. Therefore, the hypothesis is suggested as follows:

$\mathrm{H}_{1}$ : Facilities positively affect competitive advantage in the manufacturing industry.

- Inventory:

Hugos (2011) defined inventory as comprising raw materials, semi-finished and finished goods stored through supply chain by manufacturers, distributors and retailers. It is necessary for the management to decide the inventory to balance the responsiveness and effectiveness. Huge inventory allows companies to quickly meet changes in customer needs. However, larger inventory leads to a considerable cost, which influences the efficiency (Chopra \& Meindl, 2007). Inventory decisions are essential in managing the relationship between customers and suppliers. Matthew and Othman (2017) highlighted that inventory is a crucial factor in achieving competitive advantage in the manufacturing industry. In Vietnam, it is expected to exist a positive correlation between inventory and competitive advantage in manufacturers. Thus, the following assumption is suggested:

$\mathrm{H}_{2}$ : Inventory positively affects competitive advantage in the manufacturing industry.

\section{- Transportation:}

Hugos (2011) stated that transportation is the movement of everything, from raw materials to finished goods, between different locations in supply chain and a balance between responsiveness and effectiveness which is shown by choosing a 
means of transportation. Hugos (2011) also emphasized that transportation plays a crucial in the supply chain in delivering products to customers promptly. Nowadays, successful managers of supply chain need to have a broader view on the role and responsibilities of the transportation management (Somuyiwa, 2010). Matthew and Othman (2017) also found the significant correlation between transportation and competitive advantage in manufacturers. In Vietnam, the author expects that there exists a positive influence of transportation on competitive advantage in the manufacturing industry. Hence, the hypothesis is proposed as follows:

$\mathrm{H}_{3}$ : Transportation positively affects competitive advantage in the manufacturing industry.

\section{- Information:}

Information is a keystone upon which to make decisions on the other four SCM drivers including inventory, facilities, transportation and sourcing (Hugos, 2011). This driver helps increase the ability in information processing of suppliers in order to support more relations, thereby reducing uncertainty and boosting the performance of supply chain (Subramani, 2003). The study of Matthew and Othman (2017) also reported the link between information and competitive advantage in manufacturers. In Vietnam, information is anticipated to exert a positive influence on competitive advantage in the manufacturing industry. Therefore, the assumption is suggested as follows:

$\mathrm{H}_{4}$ : Information positively affects competitive advantage in the manufacturing industry.

\section{- Sourcing:}

Sourcing is a necessary activity to acquire the input for production (Hugos, 2011). Sourcing allows companies to choose the best supplier, thereby significantly affects supply chain performance. There are four key strategies adopted by manufactures to optimize their level of operations, namely focus, scaling with-out mass, disruptive innovation, and strategic repositioning resolve sourcing issues (Shahzadi et al., 2013). In Vietnam, the author expects to exist a positive relationship between sourcing and competitive advantage in manufacturers. Therefore, the following hypothesis is suggested:

$\mathrm{H}_{5}$ : Sourcing positively affects competitive advantage in the manufacturing industry.

\section{- Pricing:}

Pricing is a big factor influencing purchase decision of consumers (Haniefuddin et al., 2013). This affects the operation of supply chain management. There have been a big number of studies on pricing in supply chain management. Voeth and Herbst (2006) should be mentioned as first researchers analyzing pricing in supply chain management. Pricing is one of important factors helping gain competitive advantage. Matthew and Othman (2017) also established the correlation between pricing and company competitive advantage. In this study, pricing is anticipated to positively affect competitive advantage in the manufacturing industry. Hence, the hypothesis is suggested as follows:

\section{$\mathrm{H}_{6}$ : Pricing positively affects competitive advantage in the manufacturing industry.}

\section{Data and methodology}

\subsection{Data}

There are 205 manufacturing companies involving in the study, including 55\% of limited companies, 39\% of joint-stock companies, $10 \%$ of private companies, $5 \%$ of FDI companies and $1 \%$ of government companies. This proportion is relatively similar to weighting in manufacturing companies classified by their business forms as reported in the company survey 2018 conducted by the Vietnam's General Statistics Office, so it can reflect the overall characteristics quite accurately.

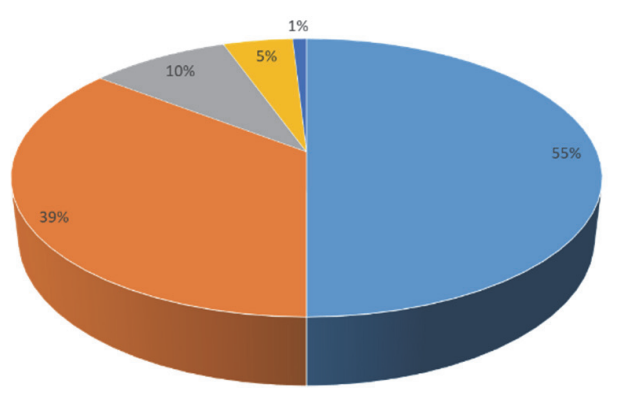

$$
\text { Limited Liability Company = - Joint Stock Company = Private company " FDI company - Government company }
$$

Fig. 1. Descriptive statistics of participants

\subsection{Methodology}

Following the previous studies, the research model is developed as follows: 


$$
\mathrm{Com}=\beta_{0}+\beta_{1} \times \mathrm{Fac}+\beta_{2} \times \operatorname{Inv}+\beta_{3} \times \operatorname{Tra}+\beta_{4} \times \operatorname{Inf}+\beta_{5} \times \mathrm{Sou}+\beta_{6} \times \operatorname{Pri}+\varepsilon
$$

Where:

Dependent variable: Competitive advantage (Com).

Independent variables: Facilities (Fac), inventory (Inv), transportation (Tra), information (Inf), sourcing (Sou), pricing (Pri).

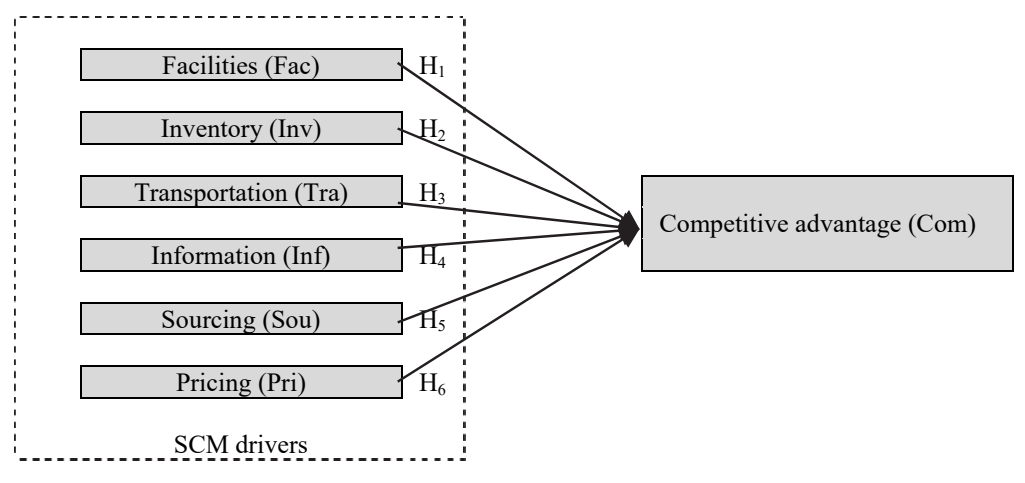

Fig. 2. Proposed theoretical model

Source: Suggested by the Author.

The study adopts the exploratory factor analysis (EFA), a multiple regression analysis, in order to establish the influence level of SCM drivers on competitive advantage in Vietnamese manufacturing companies. The exploratory factor analysis (EFA) is a technique of data reduction, allowing the extraction from observed variables into one or some latent variables (factors). This analysis also tests the convergence of observed variables in terms of each factor and its eigenvalue. Following the factor analysis, only the valid factors are included for the next analysis.

\section{Results and Discussion}

\subsection{Cronbach's Alpha test}

Cronbach's Alpha test is to examine the robustness and correlation among observed variables. Alternatively, this test is an evaluation of the reliability of the construct. This allows the elimination of inappropriate variables and constrain garbage value in the model. Particularly, only variable with the corrected item - total correlation being greater than 0.3 and alpha being greater than 0.6 is considered to be valid and included for the analyses (Nunnally \& Burnstein, 1994).

Table 1

Cronbach's Alpha

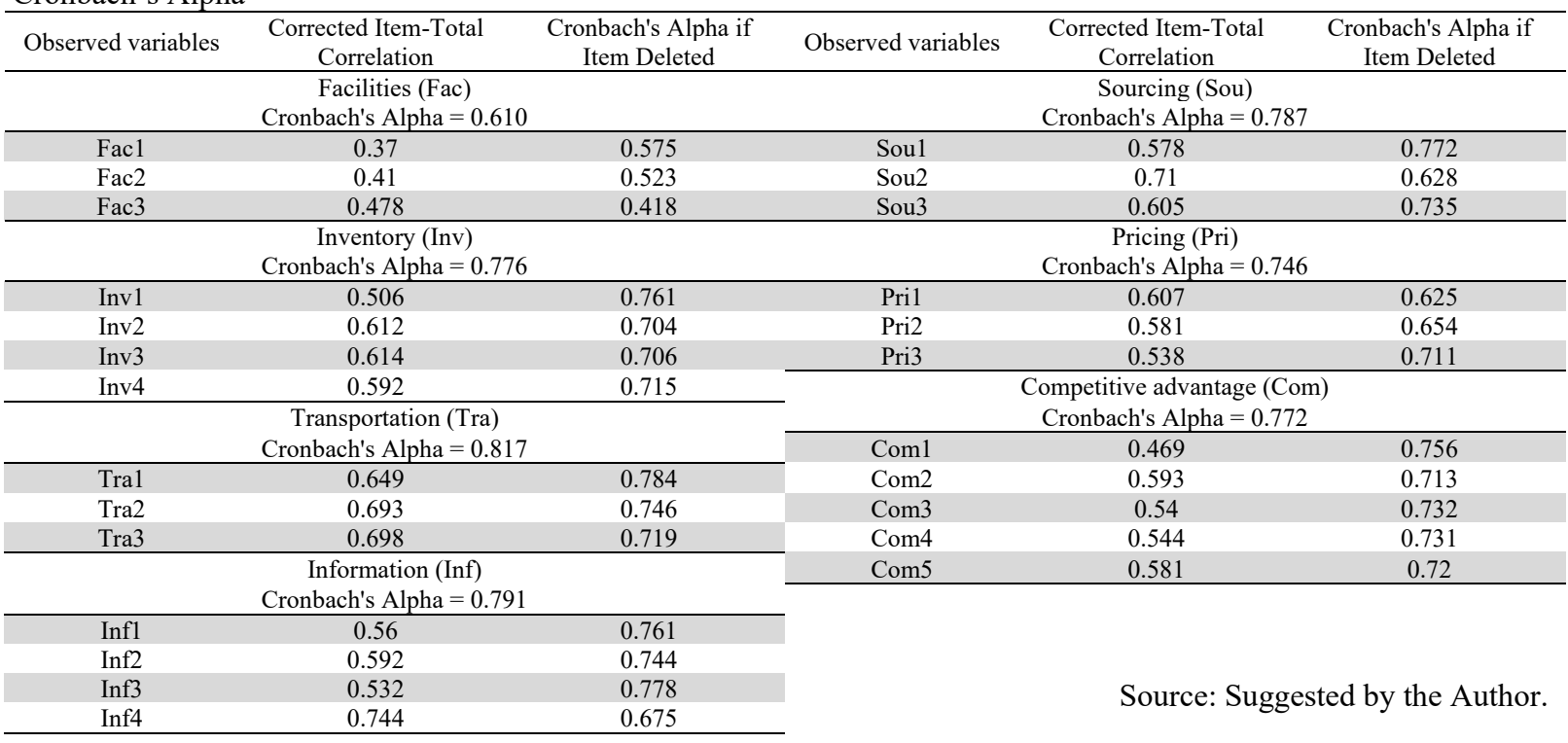

Cronbach's Alpha coefficient test results show that the variables are accepted. Specifically, all variables possess total correlation of corrected item of greater than 0.3 and alpha of higher than 0.6. 
4.2. Exploratory factor analysis (EFA)

The exploratory factor analysis (EFA) enables the data reduction from observed variables into one or some latent variables ("factors"), so the author can explore new factors in the model or confirm on the appropriateness of the previous studies.

Table 2

EFA results of independent variables

\begin{tabular}{lll}
\hline Factor loading & Result & Std. deviation \\
\hline Kaiser-Meyer-Olkin Measure of Sampling Adequacy. & 0.685 & $0.5<0.685<1$ \\
Bartlett's Test of Sphericity (Sig.) & $0.000^{* * *}$ & $0.000<1 \%$ \\
Cumulative \% & $66.282 \%$ & $66.282 \%>50 \%$ \\
Eigenvalue & 1.406 & $1.406>1$ \\
\hline Note* ${ }^{* * *}$ in
\end{tabular}

Note: ${ }^{* * *}$ indicates significance at the $1 \%$ level.

Source: Suggested by the Author.

Table 2 shows that the results of exploratory factor analysis on the independent variables are valid. In specific, KMO is 0.685 (greater than 0.5 ), the eigenvalue is 1.406 (greater than 1), cumulative of variance reaches $66.282 \%$ (greater than $50 \%$ ), and the Bartlett test is significant at the $1 \%$ level.

Table 3

Rotated Component Matrix (independent variables)

\begin{tabular}{|c|c|c|c|c|c|c|c|}
\hline & & \multicolumn{6}{|c|}{ Component } \\
\hline & & 1 & 2 & 3 & 4 & 5 & 6 \\
\hline \multirow[t]{4}{*}{ Information (Inf) } & Inf4 & 0.872 & & & & & \\
\hline & Inf2 & 0.784 & & & & & \\
\hline & Inf1 & 0.751 & & & & & \\
\hline & Inf3 & 0.716 & & & & & \\
\hline \multirow[t]{4}{*}{ Inventory (Inv) } & Inv2 & & 0.798 & & & & \\
\hline & Inv3 & & 0.785 & & & & \\
\hline & Inv4 & & 0.769 & & & & \\
\hline & Inv1 & & 0.721 & & & & \\
\hline \multirow[t]{3}{*}{ Transportation (Tra) } & Tra2 & & & 0.869 & & & \\
\hline & Tra3 & & & 0.865 & & & \\
\hline & Tra1 & & & 0.810 & & & \\
\hline \multirow[t]{3}{*}{ Sourcing (Sou) } & Sou2 & & & & 0.855 & & \\
\hline & Sou1 & & & & 0.815 & & \\
\hline & Sou3 & & & & 0.791 & & \\
\hline \multirow[t]{3}{*}{ Pricing (Pri) } & Pril & & & & & 0.838 & \\
\hline & Pri2 & & & & & 0.834 & \\
\hline & Pri3 & & & & & 0.763 & \\
\hline \multirow[t]{3}{*}{ Facilities (Fac) } & Fac3 & & & & & & 0.805 \\
\hline & Fac1 & & & & & & 0.714 \\
\hline & $\mathrm{Fac} 2$ & & & & & & 0.659 \\
\hline
\end{tabular}

Source: Suggested by the Author.

Table 3 demonstrates there are 6 independent variables extracted comprising information (Inf), inventory (Inv), transportation (Tra), sourcing (Sou), pricing (Pri) and facilities (Fac).

Table 4

EFA results of dependent variables

\begin{tabular}{ccc}
\hline Factor loading & Results & Std. deviation \\
\hline Kaiser-Meyer-Olkin Measure of Sampling Adequacy. & 0.749 & $0.5<0.749<1$ \\
Bartlett's Test of Sphericity (Sig.) & $0.000^{* * *}$ & $0.000<1 \%$ \\
Cumulative \% & $52.584 \%$ & $52.584 \%>50 \%$ \\
Eigenvalue & 2.629 & $2.629>1$ \\
\hline Note: ${ }^{* * *}$ indicates significance at the 1\% level. & & Source: Suggested by the Author.
\end{tabular}

As can be seen from Table 4, the EFA on dependent variables show valid indices (KMO, Eigenvalue, Cumulative \%). Further, the Bartlett test reveals the result is significant at the $1 \%$ level.

Table 5

Rotated Component Matrix (dependent variables)

\begin{tabular}{lcc}
\hline & & Component 1 \\
\hline & Com5 & 0.760 \\
Competitive advantage (Com) & Com2 & 0.759 \\
& Com4 & 0.727 \\
& Com3 & 0.725 \\
& Com1 & 0.649 \\
\hline
\end{tabular}

Source: Suggested by the Author.

As initially predicted, Table 5 indicates that the dependent variable of competitive advantage (Com) is extracted. 


\subsection{Estimated results of the model}

Based on the EFA results, the regression model is rewritten in the following equation:

$$
\mathrm{Com}=\beta_{0}+\beta_{1} \times \operatorname{Inf}+\beta_{2} \times \operatorname{Inv}+\beta_{3} \times \mathrm{Tra}+\beta_{4} \times \mathrm{Sou}+\beta_{5} \times \text { Pri }+\beta_{6} \times \mathrm{Fac}+\varepsilon
$$

Table 6

Estimated results of the model

\begin{tabular}{|c|c|c|}
\hline \multicolumn{3}{|c|}{ Dependent variable: Competitive advantage (Com) } \\
\hline Variables & Coef. & Sig. \\
\hline Information (Inf) & $0.360^{* * *}$ & 0.000 \\
\hline Inventory (Inv) & $0.352^{* * *}$ & 0.000 \\
\hline Transportation (Tra) & $0.509^{* * *}$ & 0.000 \\
\hline Sourcing (Sou) & $0.307^{* * *}$ & 0.000 \\
\hline Pricing (Pri) & $0.354^{* * *}$ & 0.000 \\
\hline Facilities (Fac) & $0.240^{* * *}$ & 0.000 \\
\hline $\mathrm{N}$ & & \\
\hline ANOVA (sig.) & & \\
\hline R-squared & & \\
\hline
\end{tabular}

Note: ${ }^{* * *}$ indicates significance at the $1 \%$ level.

Source: Suggested by the Author.

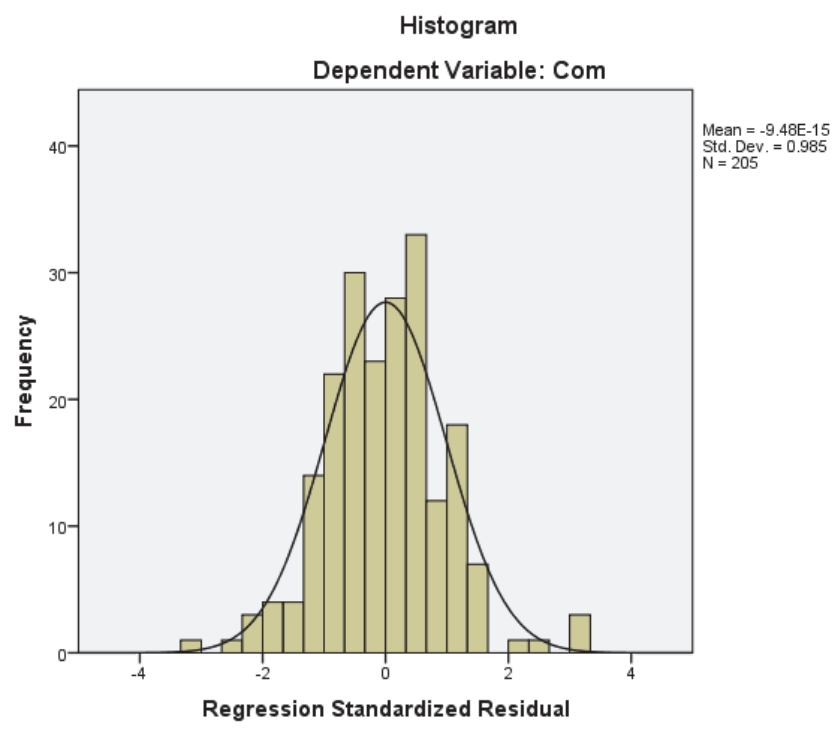

Source: Suggested by the Author.

Fig. 3. Histogram

Table 6 reveals that the model is significant at the $1 \%$ significance level. Alternatively, the estimated results are valid and utilizable. Also, R-squared is $67.3 \%$, which represents that the independent variables can account for $67.3 \%$ of variation in competitive advantage (Com). Therefore, the estimated results take the following equation:

$$
\text { Com }=0.360 * \operatorname{Inf}+0.352 * \operatorname{Inv}+0.509 * \text { Tra }+0.307 * \text { Sou }+0.354 * \text { Pri }+0.240 * \text { Fac }
$$

Moreover, the results also reveal that:

- The most significant determinant of competitive advantage in the manufacturing industry is Transportation (Tra) $(\beta=$ 0.509). This factor demonstrates the responsiveness and efficiency in selecting the transport mode. Manufacturers should pay more attention on transportation in supply chain management in order to ensure a timely delivery to customers. This result is in line with the results reported by Matthew and Othman (2017).

- Information (Inf) is the second most substantial factor affecting company competitive advantage $(\beta=0.360)$. This driver shows how effectively information is used in making wise decisions on inventory, facilities, transportation and sourcing. This driver specially becomes more essential in the current period. This factor helps increase the information processing capacity of suppliers to support more relations, which in turn enables the supply chain participants to achieve competitive advantage. This corroborates the findings of Matthew and Othman (2017).

- Pricing (Pri) is a considerable driver of competitive advantage in the manufacturing industry $(\beta=0.354)$. This result is in line with what is actually happening to the manufacturers. Pricing is one of significant factor affecting the purchase decision of customers. A suitable pricing policy can facilitate the companies in gaining competitive advantage. This finding is similar with those of Matthew and Othman (2017). 
- The result also reveals the impact of inventory (Inv) on competitive advantage $(\beta=0.352)$. Manufacturing companies need to make decisions on inventory to meet customer demand timely and effectively, thereby improving competitive advantage. Inventory was adopted as a factor by Matthew and Othman (2017) but it was not significant with competitive advantage of a manufacturer.

- Sourcing (Sor) is strongly related to competitive advantage $(\beta=0.307)$. The selection of a perfect supplier helps boosts the performance of supply chain, acquiring company competitive advantage. Good solutions of input bring manufacturers improvements in their products like prices, quality, thereby meeting growing demands of customers. Despite being included in the study of Matthew and Othman (2017), the correlation between sourcing and competitive advantage in the manufacturing industry was not significant.

- Facilities (Fac) are also considerably correlated to competitive advantage $(\beta=0.240)$. A placement at an appropriate location which is convenient for transportation, or at a suitable scale required to meet customer demands will help the supply chain perform better and manufacturing companies acquire competitive advantage. Matthew and Othman adopted facilities as a factor of competitive advantage but their relationship was not significant in the manufacturing.

\section{Conclusions}

Table 7

Results of testing hypotheses

\begin{tabular}{ccc}
\hline & Hypothesis & Results \\
\hline $\mathrm{H}_{1}$ & $\mathrm{Fac} \Rightarrow \mathrm{Com}$ & Accepted \\
$\mathrm{H}_{2}$ & $\mathrm{Inv} \Rightarrow \mathrm{Com}$ & Accepted \\
$\mathrm{H}_{3}$ & $\mathrm{Tra} \Rightarrow \mathrm{Com}$ & Accepted \\
$\mathrm{H}_{4}$ & $\mathrm{Inf} \Rightarrow \mathrm{Com}$ & Accepted \\
$\mathrm{H}_{5}$ & $\mathrm{Sou} \Rightarrow \mathrm{Com}$ & Accepted \\
$\mathrm{H}_{6}$ & Pri $\Rightarrow \mathrm{Com}$ & Accepted \\
\hline
\end{tabular}

The study has considered the impact of supply chain management drivers on competitive advantage of Vietnamese manufacturing companies. By adopting the explanatory factor analysis, a multiple regression, the author explores that all of the SCM drivers including facilities, inventory, transportation, information, sourcing and pricing are significant in helping manufacturers achieve competitive advantage. The study contributes to the current literature of supply chain. The results have crucial implications on supply chain in the manufacturing industry by recognizing the impact of SCM drivers on competitive advantage, which helps managers recognize the role of SCM drivers in gaining company competitive advantage.

\section{References}

Chopra, S., \& Meindl, P. (2001). Supply Chain Management: Strategy, Planning, and Operations, Prentice-Hall, Inc., Upper Saddle River, NJ.

Chopra, S., \& Meindl, P. (2007). Supply Chain Management: Strategy, Planning, and Operations, 3rd ed, Prentice-Hall, Englewood Cliffs, NJ.

Chotipanich, S. (2004). Positioning facility management. Facilities, 22, 364-372.

Christopher, M. (2016). Logistics \& Supply Chain Management. $5^{\text {th }}$ edition. United Kingdom: Pearson UK.

Doan, T. T. T. (2020). Factors affecting online purchase intention: A study of Vietnam online customers. Management Science Letters, 10(10), 2337-2342.

Haniefuddin, S., \& Shaik, S. B. S. (2013). Essentials of Logistics and Supply Chain Management. $2^{\text {nd }}$ edition. LPH International.

Hugos, M. H. (2011). Essentials of Supply Chain Management. New Jersey: John Wiley \& Sons

Janvier-James, A. M. (2012). A New Introduction to Supply Chains and Supply Chain Management: Definitions and Theories Perspective. International Business Research, 5(1), 194-207.

Kamath, N. (2016). Handbook of Research on Strategic Supply Chain Management in the Retail Industry. United States: IGI Global.

Lambert, D., Stock, J., \& Ellram, L. (1998). Fundamentals of Logistics Management, Chapter 14, Irwin/McGraw-Hill, Boston, MA.

Matthew, J., \& Othman, N. A. (2017). Supply Chain Management (SCM) Utilisation Based on SCM Drivers in Manufacturing Industry. Jurnal Pengurusan, 50, 123-132.

Mazlan, R., \& Ali, K. N. (2006). Relationship between supply chain management and outsourcing. Internationl Conference on Construction Industry, 21-24 June. Padang, Sumatera Barat Indonesia.

Nunnally, J. C., \& Bernstein, I. H. (1994) Psychometric theory (3rd Edtn). New York: McGraw-Hill.

Rusli, K. A., Rahman, A. A., Ho, J. A., \& Abdullah, R. (2013). How green is your supply chain? Evidence from ISO 14001 certified manufacturers in Malaysia. Pertanika Journal of Social Sciences \& Humanities, 21, 213-230.

Shahzadi, I., Amin, S., \& Chaudhary, K. M. (2013). Drivers of supply chain performance enhancing organizational output: An exploratory study for manufacturing sector. Facilities Management, 5(14), 53-64.

Somuyiwa, A. O. (2010). Impact of freight flows on city logistics in a mega-city of a developing economy. Journal of Geography and Regional Planning, 3(2), 29-34. 
Subramani, M. R. (2003). How suppliers benefit from IT use in supply chain relationships. MIS Research Center Working Paper, MIS Quarterly.

Voeth, M., \& Herbst, U. (2006). Supply-chain pricing: A new perspective on pricing in industrial markets. Industrial Marketing Management, 35(1), 83-90.

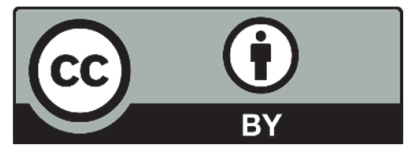

(C) 2020 by the authors; licensee Growing Science, Canada. This is an open access article distributed under the terms and conditions of the Creative Commons Attribution (CC-BY) license (http://creativecommons.org/licenses/by/4.0/). 